\title{
悪臭物質の機器分析の問題点
}

紙パルプ技術協会 環境技術委員会

\section{Some Consideration for Better Analytical Method of the Offensive Odor from Effluent flow}

\author{
Enviromental Technical Committee, JAPAN TAPPI
}

\section{（はじめに）}

要覀臭防止法施行規則の一部が改正され, 排出水中 の悪臭物質の規制基準が本年 4 月 1 日から施行された。 同時に測定方法も定められ，ヘッドスペース法とガス クロマトグラフの組合せで分析定量する事とされた。 当該方法はかなりデリケートな操作を要求される事よ り, 各社分析機関では安定的なデータを得るための 種々の工夫，検討がなされていると推察される。

この様な状況を踏まえ, 今回の環境セミナーRTD (ラウントテーブルディスカッション) では排出水中 の悪臭分析を中心として, 機器による臭気分析全般に わたる問題点, また, 平成 8 年 4 月より施行される嗅 覚测定法に係る各社の取組状況も含め, 情報交換及び 討議を進めたが, ここに各社の報告内容を項目別に取 り縓めて紹介する事とした。

\section{1. 参 加 者}

新王子製紙〔4 名〕大昭和製紙〔2 名〕

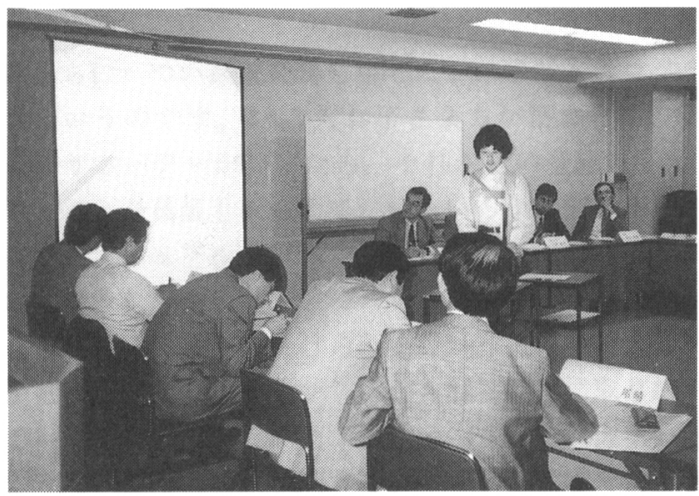

写真 RTD 発表風景
中越パルプ〔2 名〕東海パルプ〔1 名〕

日本製紙〔4 名〕北越製紙〔1 名〕

本州製紙〔2 名〕丸住製紙〔1名〕

三菱製紙〔2名〕

2. 議 事 概 要 (社名, 工場名は略)

\section{1 臭気排水の測定方法に関して}

(1) 試料の採取等

(1)公示された測定方法の記載内容に「試料水を採取 後直ちに……と時間に関して曖昧な表現がある ため, 試料水中の臭気濃度の経時变化を確認した 結果，6時間で10\%の低下が認められた（図 1)。 (2)臭気排水試料の冷却 $\left(0 \sim 5^{\circ} \mathrm{C}\right)$ に時間が掛かるた め, 試料サンプル容器も冷却し易い大きさの物を 使用している。

(3)ピペットを冷却する場合, 冷蔵庫内での臭気の污 染に注意が必要。

(2) 試料の調整等

(1)バイアルは試料水中の臭気濃度により分けて使用 している。

臭気濃度の高い排水を測定した場合，バイアルの 洗浄を㛜密に行わないと次の試料が低濃度の場合,

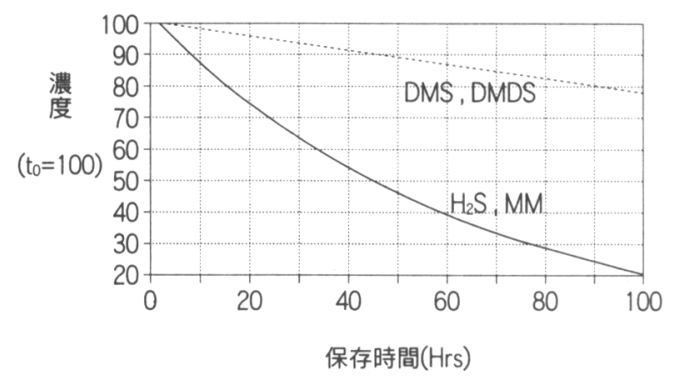

図 1 試料保存時間と水中臭気濃度の関係 
影響を与える事がある（数社より報告あり）。

(2)臭気濃度の高い排水の試料調整方法

・バイアルに予め希釈水を入れておき，シリンジで 試料水を注入。試料水を直接がスクロへ打ち込む 方法と同様值が得られた（数社より報告あり）。

・試料水をベンゼン等により溶㓮抽出する。

(3) $\mathrm{pH}$ 調節用の塩酸は試料により適宜その濃度を変 えた物を使用して $1 \mathrm{cc}$ 以内に収め, 試料が希釈 されてしまう事を防止している（数社より報告あ り)。

(4)試料をバイアルに分注後, 室温, 開封状態で試料 中の臭気濃度の变化を調査した結果，5分を過ぎ ると濃度の低下が見られた（図2)。

また，公示された測定方法の記載内容に「pH 調 整用塩酸をバイアルに注入後直ちに……」とある が, 操作は 70 秒程度必要である。

(5)公示された測定方法にある通り，バイアル中の試 料水 $\mathrm{pH}$ が $3 \sim 4$ の間にあれば，気相部臭気濃度 は殆ど变化無い事を確認（図3）。

(6)同様に, $30^{\circ} \mathrm{C}$ の恒温水槽に於ける保持時間につい ては最低 30 分間必要である事を確認した（図4）。

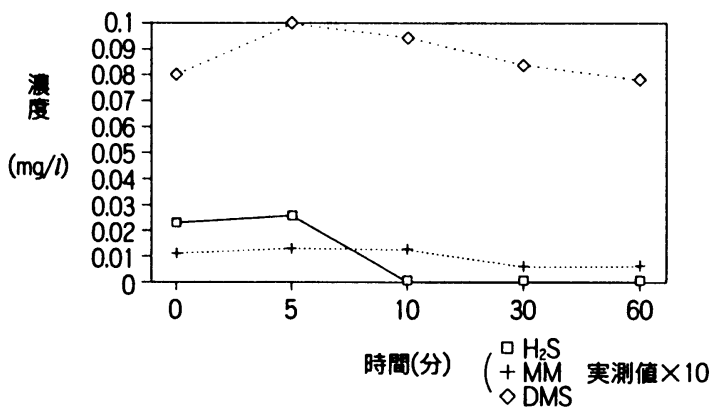

図 2 バイアル中の試料放置時間と水中臭気濃度の関 倸

注）バイアルに試料分注後, 室温, 開封状態で 放置。

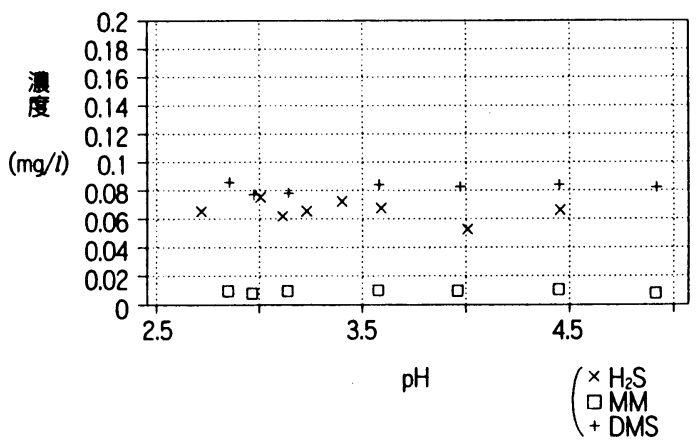

図 3 バイアル中試料の $\mathrm{pH}$ と水中臭気濃度の関係
(3) 試料の分析等

(1)試料水中の VOC は分析を妨害するので注意を要 する。

(2)MM と DMS は検出限界が高く, 規制値の 10 分 の 1 以下にならない（数社より報告あり）。

(3)測定値のバラッキについて。

・今回の出席各社について，バラッキが極めて少な いと言う所から CV 值で $200 \%$ を示す所まで，習 熟度により大きな差が見られた。

・ある事業所の例では, 試料間の CV 值は $20 \%$ 以, また測定者間の CV 值は $15 \%$ 以下となっている。

・測定值の中では特に $\mathrm{H}_{2} \mathrm{~S}$ のバラッキが大きい (数社より報告あり)。

(4)公示された排出水中の臭気濃度測定法は工場総合 排水程度の臭気濃度の測定を目的としているため, 臭気濃度が高い排水の場合は測定方法に示されて いる濃度計算用係数が当てはまらず，低い值を示 してしまう（数社より報告あり）。

\section{2 機器分析に関して}

(1) カラム剤の種類

カラム剤の種類により， $\mathrm{SO}_{\mathrm{x}}, \mathrm{COS}, \mathrm{CS}_{2}$ 等の妨害 物質の影響を各々受けてしまう。

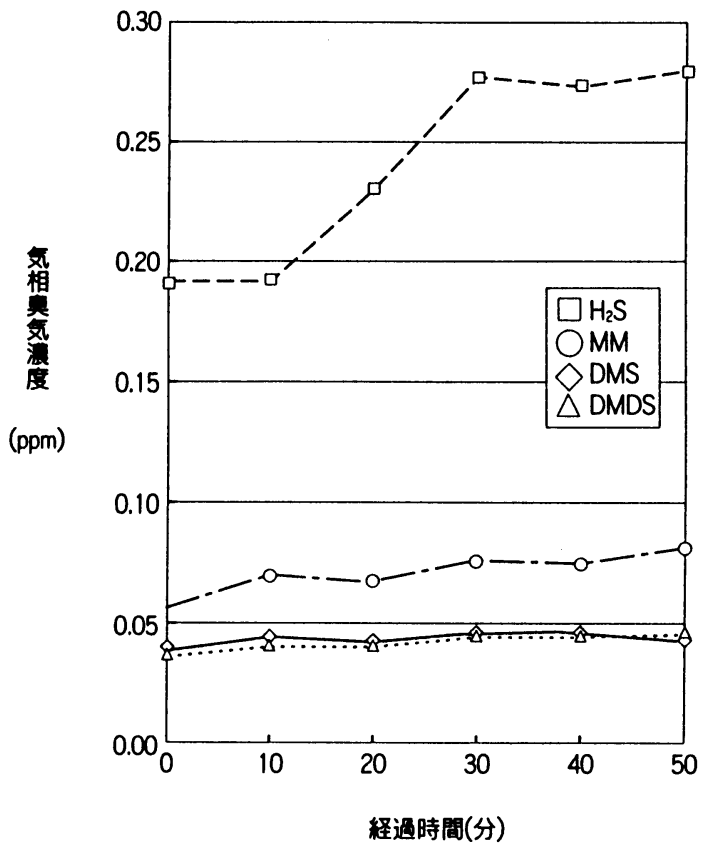

図 4 恒温水槽保持時間と気相部臭気濃度の関係

注）試料液中温度が 20 分経過しないと, $30^{\circ} \mathrm{C}$ に達していない。このため気相臭気濃度で比較 した。 
対策として

(1)二度手間となるが, 同じ試料をカラム剤を変えて 分析する $(\beta-\beta \mathrm{ODPN}$ 及び PPE 各々で分析)。

(2)力ラム剤を混合使用する方法を 2 社で採用。内 1 社は地方自治体からの要請に基づき実施中（表 1 及び図5)。
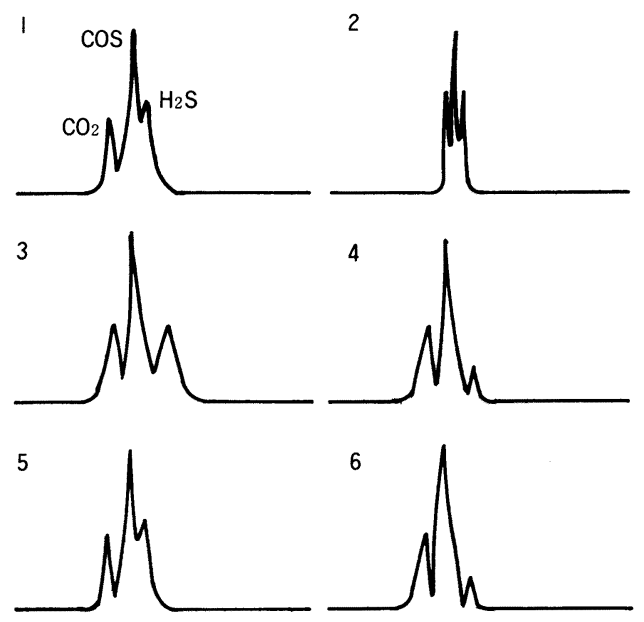

7

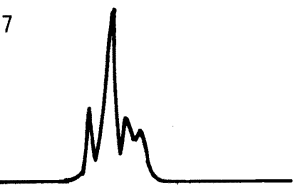

8

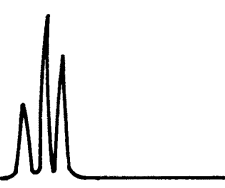

図 5 カラム充填剤と $\mathrm{H}_{2} \mathrm{~S}$ 分離状態
(3)カラム長を $3 \mathrm{~m}$ から $5 \mathrm{~m}$ 一延長。この結果リテ ンションタイムが延びるため, 昇温法からアイソ サーマル法へ変更。

(4)カラム温度, キャリヤーガス圧の変更で対処（数 社より報告あり)。

(2) ガスクロの感度アップ対策

(1)カラムの充坨剤の更新（数社より報告あり)。 (2)燃焼石英管の早めの交換（数社より報告あり）。

(3)ホトマル (光電子増幅管) 電圧アップ。

(4)燃焼ガス $\left(\mathrm{H}_{2}\right)$ 流量の変更。

(5)フレーム位置の変更（機種により不可の場合あ り)。

(3) ガスクロへの試料打込み操作に伴うバラッキ対 策

(1)試料打込み用シリンジ（ピストンパッキン）は老 朽化前（操作に抵抗感が無くなった時点）に交換 する必要あり(図6)。

(2)試料打込み用シリンジの針は横穴式を使用（数社 より報告あり)。

(4) 検量線の作成方法

(1)校正用標準物質の違いによる測定精度への影響度 をチェックした結果, $\mathrm{CV}$ 值で比較すると, $\mathrm{H}_{2} \mathrm{~S}$ の場合ガスボンベ $=6.9 \%$, パーミエーションチ ューブ $=3.2 \%$ ，また MMの場合標準試薬 $=9.5 \%$, パーミエーションチューブ $=5.4 \%$ であり，いず れもパーミエーションチューブのバラッキが小さ

表 1 カラム充填剂一覧

\begin{tabular}{|c|c|c|c|c|c|c|}
\hline 充填剤 & (1) & (2) & (3) & (4) & (5) & 備 \\
\hline 品 名 & PPE & PPE & TCEP & TCEP & TCEP & \\
\hline 粒 度 & $60 \sim 80$ & $60 \sim 80$ & $60 \sim 80$ & $60 \sim 80$ & $80 \sim 100$ & \\
\hline コート量 & 15 & 10 & 20 & 25 & 25 & \\
\hline \multicolumn{7}{|l|}{ テスト No } \\
\hline 1 & 100 & & & & & 従来使用品 \\
\hline 2 & & 45 & 55 & & & 自治体測定機関使用品 \\
\hline 3 & & & & 100 & & \\
\hline 4 & & & & & 100 & \\
\hline 5 & & & 100 & & & \\
\hline 6 & 60 & & & 40 & & \\
\hline 7 & & 45 & & 55 & & \\
\hline 8 & & 45 & & & 55 & 現在使用品 \\
\hline
\end{tabular}

注） 2 種の充填剤は, 重量比混合による。 


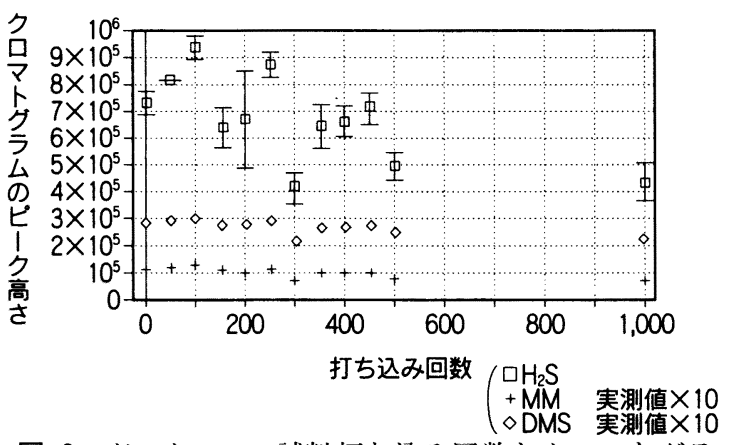

図 6 ガスクロへの試料打ち込み回数とクロマトグラ ムのピーク高さの関係

W。

(2) $\mathrm{H}_{2} \mathrm{~S}$ についてはカラムにより経時的な変化がみ られる場合があるため, 測定の都度, 検量線を引 き直す（数社より報告あり）。

(3)検量線は微妙にカーブしており，2 点で線引きす るのは危険。作業能率も考慮の上, 出来るだけ点 数を多くすべき（数社より報告あり)。

(5) その 他

自治体と測定方法に差がみられる所がある一方

で，自治体で使用している機種に合わせて同種の ガスクロを購入して両者の分析を誤差を縮める努 力をしている工場もあった。

\section{3 嗅覚測定法に関して}

(1) パネラーについて

(1)喫煙の有無, 年魿の差など個人間の差が大きく, 選定時には種々の配慮が必要。

(2)自社内からパネラーを選定する場合，小所帯の工

場等ではその維持が難しい場合が多い。

(3)自治体の立入調査を受け, 工場でも同時測定を実
施したい場合パネラー対象者を多数用意していな いと，緊急にパネラーを集めるのは困難である。

(2) 测定に関して

(1)パネラーの疲労を考虑すると， 3 サンプル程度が 限度の様である。

(2)サンプルは経時変化し, 嗅覚測定濃度は低下する 様である。

(3) その 他

臭気判定技師の資格取得について，講習会も定 員いつぱいで，取りたくても取れない状況にある。 是非とも国側の対応を急いで欲しいとの要望が多 かった。

\section{おわりに}

分析でも臭気分析は難しいとされているが，各社と も大変苦労してその精度維持向上に取組んでいるか伺 い知る事が出来た。また今回の会議から自治体側と細 部の測定方法を統一化しておく事が今後ますます重要 になって来ると予想されるので, 自治体側との情報交 換を進める一方, 各社の更なる分析技術の向上を期待 する。

なお，RTDの内容については非公開を原則として いるが, 当 RTDに参加されなかった多くの分析担当 者に少しでもお役立て頂きたく, 内容を公開する事と した。また, 記載内容については各社それぞれの意見 を載せたものであり, 当 RTDの総意を得たものでは 無い事を申し添える。

最後にRTDへの参加各社, そしてデー夕等提示頂 いた各社に当紙面を借りて心から御礼申し上げます。

（三菱製紙(株)金田 裕, 北越製紙(侏)内山公男 記) 